\title{
Geozoology in Mineral Exploration
}

\author{
by Robert R. Brooks
}

\begin{abstract}
Geozoological methods of mineral exploration involve the use of animals either indirectly or directly. The author reviews how various mammals, fish and insects can be used in searching for minerals. He describes in particular how dogs and termites can be used as voluntary and involuntary "field assistants". The ideas presented here will assist in bringing to the attention of research workers a very neglected field of mineral exploration.
\end{abstract}

\begin{abstract}
Introduction
At first sight the idea of using animals as field assistants may seem ludicrous. However there is evidence that such dissimilar animals as dogs and termites can be of use in mineral prospecting. The literature shows that these and other animals have been used either directly or indirectly for this purpose. I use the term geozoology to describe all methods of prospecting involving the direct or indirect use of animals, whether these methods are visual (e.g. study of animal behaviour) or involve chemical analysis (e.g. of trout livers or termite mounds).
\end{abstract}

The science of $g$ :ozoology, though new in name, has its roots in antiquity, for Herodotus reported in 450 B.C. that certain "tribes" in India studied termite mounds to detect gold mineralization. "There is found in this desert a kind of ant of great size - bigger than a fox though not as big as a dog. These creatures as they burrow underground throw up the sand in heaps just as our own ants throw up the earth, and they are very like ours in shape. The sand has rich content of gold, and it is this that the Indians are after when they make their expeditions into the desert." Herodotus may have exaggerated the size of the termites, but there seems no reason why termitaria could not have been used for prospecting purposes even then.

It is only recently, however, that geozoological methods have had a wider application in prospecting. Because of the basic problems of the relative mobility of most (though not all) animals the potential of this approach is obviously not as great as that of botanical methods. There are, however, animals so restricted in their habitat that they can provide clues to the location of mineral deposits.

\section{Effects of Toxic Metals on Land Mammals}

Land mammals can be used to indicate mineralization by clinical symptoms of heavy metal poisoning, by symptoms caused by an excess of one element in the animal, and through their direct use as "field assistants". It has long been recognized that plants and animals may be influenced by the chemical environment from which they obtain their nutrients. Some form of endemic disease or condition which readily distinguishes one district from others nearby, can usually be related to an excess or deficiency in one particular element or group of elements. Classical examples are the symptoms of iodine deficiency in humans and animals and the effect of soils from ultramafic rocks on vegetation. Such biogeochemical provinces (Vinogradov, 1964) usually either involve deficiencies in elements (e.g. Ca, Co, I) due to the nature of the soils in the area, or are influenced by local enrichment of elements from ore bodies and their dispersion halos.

In domestic animals, nutrition and health are influenced by the composition of their food, which may involve gross deficiencies in or toxic excesses of particular elements, or variations in the relative proportions of these metals. Supplementary diets not necessarily of local origin can, of course, confuse the picture by modifying the influence of the local biogeochemical province.

The study of the geographical nature of human disease is known as epidemiology, a very controversial field where almost any findings are likely to be subject to widespread questioning and criticism. The link between human health and geology is exceedingly complex, because we are generally very mobile and our food and drink are not necessarily locally derived.

One of the many human diseases said to be possibly caused by relatively high levels of heavy metals (e.g. Cu, $\mathrm{Pb}$ and $\mathrm{Zn}$ ) in the environment is multiple sclerosis. The same elements are said to produce the disease known as Balkan neuropathy, and high levels of arsenic are thought to produce blackfoot disease in Taiwan (Hopps, 1971). It is well known (Grantham and Jones, 1977) that near Halifax, Nova Scotia, sickness and even death are caused by high levels of As in drinking water supplies derived from nearby gold mine workings where arsenic is geochemically associated with the gold.

The relationship between diseases in domestic animals and mineralization was highlighted by a monumental study carried out by J.S. Webb and his associates (Webb et al., 1968a, 1968b) at Imperial College London. In 1965, the group carried out a geochemical reconnaissance survey of stream sediments in England and Wales. Some 50000 samples (one per square mile) were analyzed for about 20 elements and the data displayed separately for each element in a synoptic geochemical atlas. The survey highlighted many areas of trace element excesses or deficiencies, and correlations were made with previously-recorded instances of diseases caused by imbalances in heavy metals.

One of the most important of the above discoveries is shown in Figure 1. A geochemical map of Mo distribution in Derbyshire (Webb et al., 1968b) showed significant anomalies in the streams that flow from the vicinity of a contact between limestone and younger sandstones and shales. The same figure shows the distribution of the occurrence of hypocuprosis (deficiency of $\mathrm{Cu}$ in the blood) among cattle. This deficiency is certainly caused by the antagonistic ef- 
Molybdenum stream sediment anomaly

- Reported incidence of hypocuprosis

$0 \longdiv { 5 1 0 } \mathrm { km }$

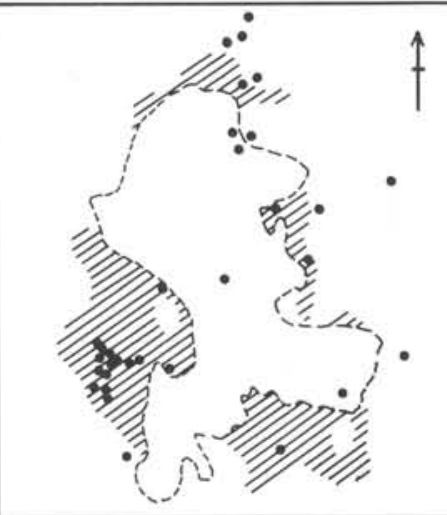

Figure 1: Mo in stream sediments of Derbyshire, England, as related to the occurrence of hypocuprosis in sheep and cattle. The central region bounded by a broken line is a limestone outcrop. From Webb et al. (1968b) with permission from Nature.

fects of high Mo levels in the environment, and the degree of correlation in this case is remarkable.

A more direct indication of mineralization in Derbyshire is a reflection of the residual toxicity of ancient $\mathrm{Pb}$ mines dating back to Roman times. For example, farmland adjacent to Roman lead workings where several cattle and ponies had died from suspected $\mathrm{Pb}$ poisoning was found to contain up to $200 \mu \mathrm{g} / \mathrm{g}$ of $\mathrm{Pb}$ (dry weight) in the grass of the pastures of the area (Chisnall and Markland, 1971).

The best known ore discovery originating from observation of toxic effects in animals was on the Colorado Plateau. This was as a consequence of the knowledge that certain widespread plants (particularly those of the genus Astragalus) were extremely poisonous to livestock (Beath et al., 1939). The cause of the toxicity was finally recognized as selenium, accumulated in large amounts by the Astragalus plants. Since the seleniferous ground often contains associated U, Cannon (1957) was able to use the distribution of Astragalus to indicate $U$ mineralization at depth. Involved thus was a chain of four factors: sick animals - plant indicators of Se association of Se and U - discovery of U.

This study was of great importance because it was carried out as a logical follow-up of observed diseases in animals. The other situations quoted above were retrospective, but there is no reason to suppose that intelligent assessment of the original clinical condition could not have led to a mineral discovery. After all, over four centuries ago Agricola pointed out that minerals produce stunting and other morphological symptoms in plants and animals.

Of course, studies of animal diseases alone are not likely to lead to spectacular mineral discoveries. They may, however, reveal biogeochemical provinces in which other prospecting methods can reveal the presence of anomalies or ore deposits. Unlike plants, however, animals are not readily spotted by remote sensing methods, so that geozoology is never likely to be as effective as geobotany in mineral exploration.

\section{Dogs as Mineral Sniffers}

However fanciful it may seem, four countries have trained dogs to scent out sulphide-rich boulders and ore deposits. The pioneering work began with the investigations of Dr. Aarno Kahma of the Geological Survey of Finland, based on the assumption that a trained dog with its very keen sense of smell should be able to detect a weathered sulphide boulder from a distance of several meters, and possibly even below the surface.
Kahma selected an Alsatian (German Shepherd) dog and trained it for two years before a practical field test in 1964, which was successful. In 1965 the dog, "Lari", was pitted against a human boulder prospector (Fig. 2). In a $3 \mathrm{~km}^{2}$ field, Lari found 1330 sulphide-bearing boulders, some of which were buried deeper than $10-20 \mathrm{~cm}$, while the prospector found only 270 surface boulders. In that same summer, Lari also located pyrite and chalcopyrite float on another site, and as a result a copper orebody of economic significance was later encountered here by diamond drilling. A reward of $\$ 2000$ was paid to the trainer by the Finnish Government and a smaller sum to the originator of the idea. Lari was rewarded with four sausages!

Kahma's work was not reported until much later (Ekdahl, 1976; Kahma et al., 1975) but the idea of using dogs quickly spread to Sweden (Nilsson, 1973), the Soviet Union (Orlov et al., 1969) and Canada (Brock, 1972). The Geological Survey of Finland now uses a number of dogs in routine prospecting. Experience of the use of dogs in Sweden has been summarized by Nilsson (1973), from whose work the following information is derived.

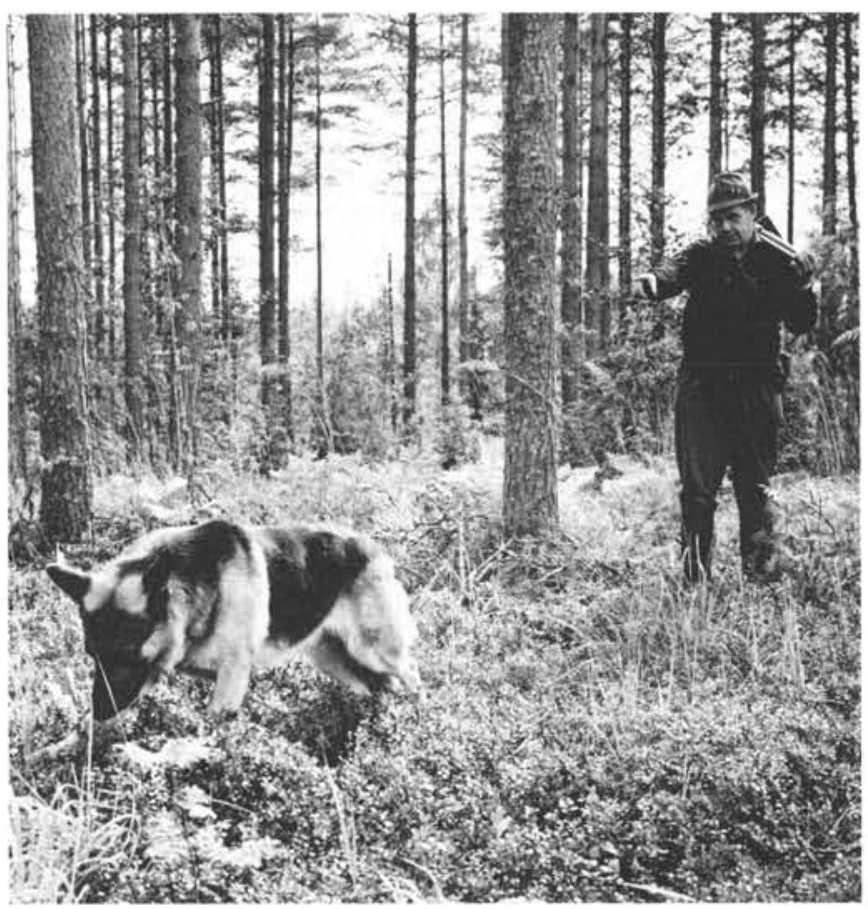

Figure 2: "Lari", the world's first ore-sniffing dog pictured in Finland. (Photograph by courtesy of P. Mattson).

In 1973 the Swedish Geological Survey had four prospecting dogs and gave the trainers a course in boulder searching. At the Dog Training Centre, each dog must pass suitability tests involving sense of smell, defence and endurance. The training centre has always chosen Alsatians since they possess the necessary strength and energy for boulder searching. The Labrador Retriever is thought to be another useful type of breed because of its fine sense of smell.

The training is intended to develop a desire on the part of the dogs to locate sulphide-bearing rocks and to defend them. Advantage is taken of the dog's fighting spirit. Initially the dogs are taught to retrieve various sizes and types of sulphide-mineralized rocks thrown out by the trainer. Some of these rocks contain no sulphides. If the specific rock does contain sulphides, the trainer tries to get the dog to defend it by pretending to take it away from the animal. When the dog's defence of sulphide boulders has reached the point of aggressiveness, it is then trained to search for mineralized 
boulders on its own initiative and to mark the spot by barking.

The dogs are able without difficulty to locate boulders containing relatively small amounts of pyrite, pyrrhotite, chalcopyrite or arsenopyrite which are covered by $10-20 \mathrm{~cm}$ of soil. Several cases have been reported of dogs having located boulders buried at a depth of $1 \mathrm{~m}$ in a boulder pile. One report from the Soviet Union stated that dogs have located orebodies covered by alluvial sediments $12 \mathrm{~m}$ thick.

A case history from Finland (Ekdahl, 1976) is illustrated in Figure 3, which represents a site where a weakly-mineralized outcrop was known. A prospecting dog showed heightened interest at the sites marked with crosses on the figure. Trenching of an EM anomaly found subsequently here revealed the presence of disseminated pyrrhotite and chalcopyrite in a highly-weathered zone overlain by $2 \mathrm{~m}$ of sand and clay.

In Canada, experience with dogs has been less encouraging (Brock, 1972). Nevertheless, some success was achieved with two Alsatians whose training was based on the animals' love of play rather than on their aggressive instinct. The dogs were trained to fetch rocks thrown by the trainer. Bringing back a sulphide-bearing rock earned a reward, whereas nonmineralized retrievals involved a reprimand. After about two months, the dogs were able to find medium- to high-grade rocks which had been buried under $3 \mathrm{~cm}$ of soil.

The obvious ability of dogs to detect sulphides may have applications which overlap into geobotany. In Western Australia most native plant species have a characteristic smell which the field worker can readily recognize and which can serve as a guide to identification. For example, I can myself readily recognize from its odour alone the nickel indicator and hyperaccumulator, Hybanthus floribundus (Severne and Brooks, 1972). A well-trained dog should thus be able to perform very much better than a human assisting geobotanists to identify indicator plants.

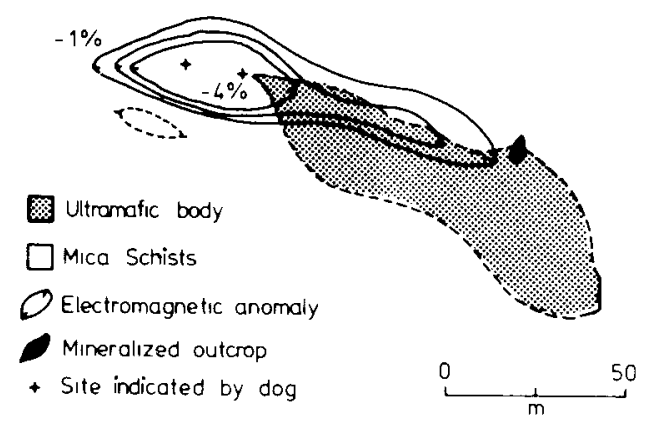

Figure 3: Site where a dog detected sulphide mineralization beneath a $2 \mathrm{~m}$ overburden at Pielavesi, Finland. From Ekdahl (1976).

The limiting factor for use of prospecting dogs is undoubtedly the cost and the time required for training. They are, therefore, not likely to be used on a global basis but would rather be confined to cold-temperate and sub-Arctic regions where there is an extended winter period without extraneous odours to distract them.

\section{Fish - Useful Indicators}

Warren and others (1971) were among the first to point out the potential use of fish in mineral exploration. These workers analyzed the livers of 96 rainbow trout and cutthroat trout from various localities in British Columbia. All the livers with $>50 \mu \mathrm{g} / \mathrm{g}$ (micrograms per gram, or ppm) $\mathrm{Zn}$ (wet weight) were from fish living in waters known to be associated with economic $\mathrm{Zn}$ mineralization. Of 17 localities where livers showed $>60 \mu \mathrm{g} / \mathrm{g}$ copper, four were known to contain significant mineralization and another seven merited further investigation on the basis of their known geology.
The other six areas were ignored because of unfavourable geology. Warren and his colleagues also analyzed trout livers from a highly mineralized stream in West Devon, England, finding highly-anomalous $\mathrm{Cu}$ levels $(100-340 \mu \mathrm{g} / \mathrm{g})$ in three samples.

Later, Ward (1973) reported Mo levels in tissues of rainbow trout (mean of $2233 \mu \mathrm{g} / \mathrm{g})$ and kokanee salmon $(100 \mu \mathrm{g} / \mathrm{g}$ ) from waters varying greatly in Mo content. Despite a good correlation between the two variables, increases in fish were only slight for increasing amounts of Mo in the waters. To study the dispersion of these elements from geothermal regions of New Zealand, levels of $\mathrm{Cd}, \mathrm{Cu} \mathrm{Fe}, \mathrm{Hg}, \mathrm{Mn}$ and $\mathrm{Zn}$ were determined in organs of 111 specimens of rainbow and brown trout (Brooks et al., 1976). The results showed a good correlation between elemental levels and the degree of geothermal activity. Livers contained up to $506 \mathrm{\mu g} / \mathrm{g}$ (wet weight) of $\mathrm{Cu}$ and up to $60 \mu \mathrm{g} / \mathrm{g} \mathrm{Zn}$. It is of interest to note that they also contained up to $1.3 . \mu \mathrm{g} / \mathrm{g} \mathrm{Hg}$, well above the normally accepted level of $0.5 \mu \mathrm{g} / \mathrm{g}$ established by most health authorities.

Bollingberg (1975) was the first to suggest that seaweed, shellfish and pelagic fish could be used for mineral prospecting. His work was carried out in the vicinity of relatively undisturbed $\mathrm{Pb}-\mathrm{Zn}$ ores of the Quamarujuk Fiord in west Greenland. For example, lead concentrations in the mussel Mytilus edulis, increased from 2.2 to $22 \mathrm{\mu g} / \mathrm{g}$ (wet weight) near the ore deposit. Similar findings were reported for $\mathrm{Cu}(1.1$ to $5.4 . \mu \mathrm{g} / \mathrm{g})$, Cd $(<0.5$ to $0.6 \mu \mathrm{g} / \mathrm{g})$ and $\mathrm{Zn}(5.2$ to $36 \mu \mathrm{g} / \mathrm{g})$. Later in the same area, Bollingberg and Johansen (1979) found that lead levels in wolffish livers, which ranged up to $142 \mu \mathrm{g} / \mathrm{g}$ prior to mining, increased fivefold after $\mathrm{Pb}-\mathrm{Zn}$ mining had begun.

Obviously, analysis of fish livers can only be effective for prospecting if the species are confined to a fairly small area. Migratory salmon, for example, could hardly be used, and it is difficult to imagine that any oceanic pelagic fish might be used for this purpose. The usefulness of shellfish is, however, further supported by Butterworth and others (1972), who found anomalous levels of $\mathrm{Cd}$ and $\mathrm{Zn}$ up to $140 \mathrm{~km}$ along the coast away from the Avonmouth smelter in England. Even though this was a result of pollution from a smelting complex, the very high degree of concentration of trace elements from sea water by shellfish (of the order of one million times for some elements) makes them very sensitive indicators of potential mineralization. Furthermore they have the advantage of being easy to obtain and of having a relatively fixed habitat.

\section{Insects - Still More Useful}

The direct use of insects for mineral exploration has no advantage over soil or vegetation sampling, which is easier and more reliable. It is not surprising therefore that the literature concerning elemental uptake by insects is very sparse as related to mineral prospecting.

An interesting survey of the metal content of termites carried out by Wild (1975) on Odontotermes transvaalensis and Trinervitermes dispar located in termitaria (mounds) on serpentinites of the Great Dyke of Zimbabwe. Workers of both species contained high levels of $\mathrm{Ni}$ and $\mathrm{Cr}$ of up to 2000 and $1500 \mathrm{\mu g} / \mathrm{g}$ (dry weight) respectively. A similar high level of $\mathrm{Ni}$ and $\mathrm{Cr}(2000$ and $2500 \mu \mathrm{g} / \mathrm{g}$ dry weight) was observed in a tenebroid beetle (Catamerus sp.) from the same area. It is interesting to note that the soldiers contained less than 300 $\mu \mathrm{g} / \mathrm{g}$ for both elements, and the queens less than $20 \mu \mathrm{g} / \mathrm{g}$ and $30 \mathrm{\mu g} / \mathrm{g}$ respectively. The explanation for this is that the workers feed directly on the $\mathrm{Ni}$ - and $\mathrm{Cr}$-rich vegetation, whereas the soldiers and queens are fed second-hand by the saliva of the workers who have presumably decontaminated this liquid by absorption of heavy metals into their own bodies.

It is hardly worthwhile to analyze termites at random for their $\mathrm{Ni}$ and $\mathrm{Cr}$ content as a means of detecting serpentinite 


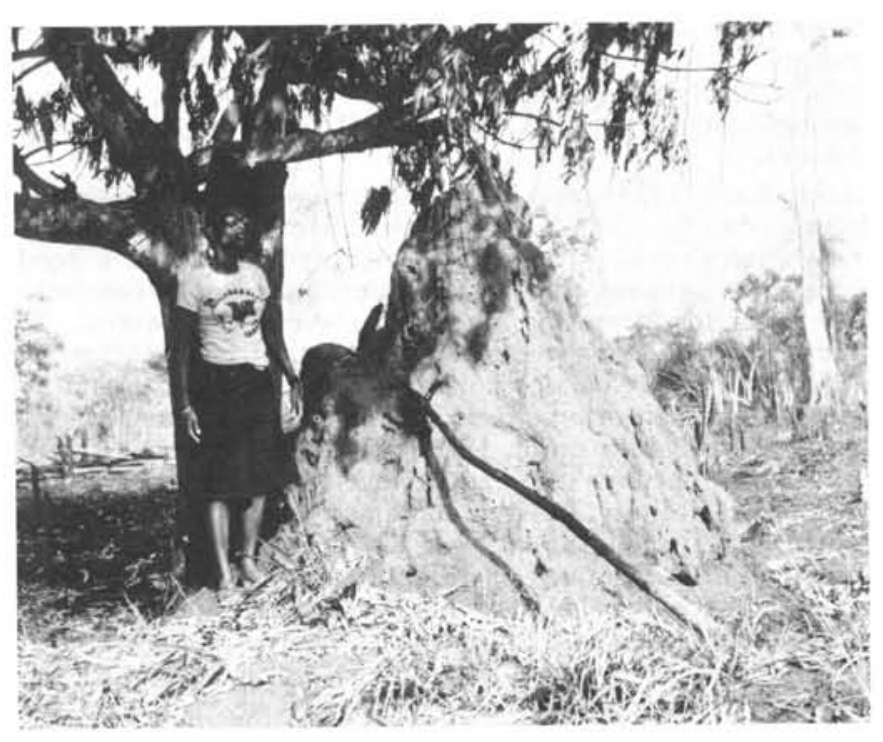

Figure 4: Typical termite mound, near Volta River Dam, Ghaña.

because this rock type is so well defined by the visual appearance of its vegetation alone. However, two novel indirect methods for the use of insects in mineral exploration have been suggested.

Makarochkin and Yudenich (1960) proposed that the composition of honey may indicate the elemental content of the soil in which the nectar-producing plants originally grew. They found elevated levels of $\mathrm{Mo}(200 \mu \mathrm{g} / \mathrm{g})$ and $\mathrm{Cu}(100 \mu \mathrm{g} / \mathrm{g})$ in the ash of honey from the Lake Ilmen area of the U.S.S.R. These they presumed were due to higher than normal concentrations of these elements in the local soils.

In a further extension of this work, Makarochkin and Yudenich (1962) observed that the Mo, Cu and $\mathrm{Ti}$ contents of honey ash from the southern Urals were significantly higher than in the local rocks, and they discussed possible applications to prospecting. Later, Makarochkin (1972) analyzed honeys from widely-separated districts of the Soviet Union to indicate geographical differences in trace element contents of the soils.

There appears to be no reason why honey could not be used as a sampling type of mineral exploration. Bees do not usually forage more than a kilometer or so away from the hive and the honey that they produce is therefore indirectly indicative of the immediate environment. Bees themselves, however, have seldom been analyzed, though Razin and Rozhkov (1966) reported about $20 \mathrm{ppb}$ (nanograms per gram) gold in Vispidae sp.

In an interesting variant of honey analysis, Warren (1980) reported that pollen collected from hives in a lead-mining district of Devon, England had five to ten times more $\mathrm{Pb}$ than pollen collected from Norfolk, which possesses no lead deposits. Warren also found significantly higher than background levels of $\mathrm{Cd}, \mathrm{Cu}, \mathrm{Pb}$ and $\mathrm{Zn}$ in pollen collected from mineralized areas of British Columbia, Canada.

Techniques involving bees, honey and pollen are admittedly somewhat esoteric. They will obviously need to be proved by extensive experience and scientific testing before they are accepted by the scientific community. In contrast, the use of termites as "field samplers" is one of the best proven and potentially most useful geozoological techniques.

The use of termites and termite mounds (Fig. 4) is best illustrated by an example from the Leopard Mine in Zimbabwe. According to W.F. West (1965), then mine manager, "termite colonies abound in this country and they cannot exist without water. Owing to the intermittent rainfall, they must depend on underground water supplies to keep them alive for six to nine months each year and the water must come from water-carrying fissures. In the Leopard Mine their water-carrying passages extend down to the $60 \mathrm{~m}$ which is the present water level. The termites mine their way down the softer sections of the surface rocks to obtain the water, these softer sections obviously being the dried-up portions of the water-carrying fissures, and in the case of the Leopard Mine, the ore-bearing fissure.

"In mining their way downwards to water, they remove the necessary spoil and bring it to the surface to be deposited in the form of a heap known as an ant heap. Two things are obvious: (a) that the termites have located a fissure, and (b) that they have brought a form of sample of the material contained in that fissure, to the surface. Some of the termite heaps on the Leopard and Leopardess Mines yield more than $3 \mathrm{~g}$ of Au per tonne of material per sampling, and these are located on fissures containing payable orebodies that are at present being profitably mined. The plotting and sampling of termite heaps, irrespective of the nature of the overburden (such as Kalahari sands), is a useful and accurate method of prospecting with this advantage, the onerous part of the work has already been done by the termites at no cost to the prospector." Figure 5 shows schematically the results obtained near the Leopard Mine.

West's anthill theory was at first greeted with some ridicule. Ultimately however he excited the interest of the Minister of Mines, who observed that the technique had been used to discover a Au anomaly concealed by an overburden of Kalahari sand, which commonly covers outcrops over much of south-central and southern Africa. However, follow-up work carried out by Watson (1972) did not substantiate West's claims, indicating that the termites may have carried their mound material from a depth of less than $3 \mathrm{~m}$ rather than from the water table at $227 \mathrm{~m}$. The same author also reached similar conclusions for a $\mathrm{Zn}$ anomaly covered by Kalahari sand in western Zimbabwe (Watson 1970).

A later study by West (1970) did however appear to vindicate his earlier thesis. An area of $10 \mathrm{~km}^{2}$ in the Silobela area, some $80 \mathrm{~km}$ west of Que Que, Zimbabwe, was selected for a test. This area was covered with an overburden of $1-3 \mathrm{~m}$ of soil derived largely from non-mineralized Kalahari sand. It also included three 15 th Century gold mines that had been worked in modern times. Samples from $45 \mathrm{~cm}$ below the highest point of each termite mound were analyzed for Au. Anomalously high Au levels were found in groups of ant hills which coincided almost exactly with the payable sections of three mines. Another traverse in a different area showed traces in the termitaria of $\mathrm{Au}, \mathrm{Zn}, \mathrm{Pb}, \mathrm{Mo}$ and $\mathrm{Ag}$ mineralization. The Mines Department then sank a shaft into a $\mathrm{Zn}$ $\mathrm{Ag}$ anomaly and exposed a zinc-silver reef at $10 \mathrm{~m}$ below the surface.

Further evidence of the usefulness of termitaria in prospecting for minerals was furnished by d'Orey's (1975) work over a small Cu deposit at Vila Manica in Mozambique close to the

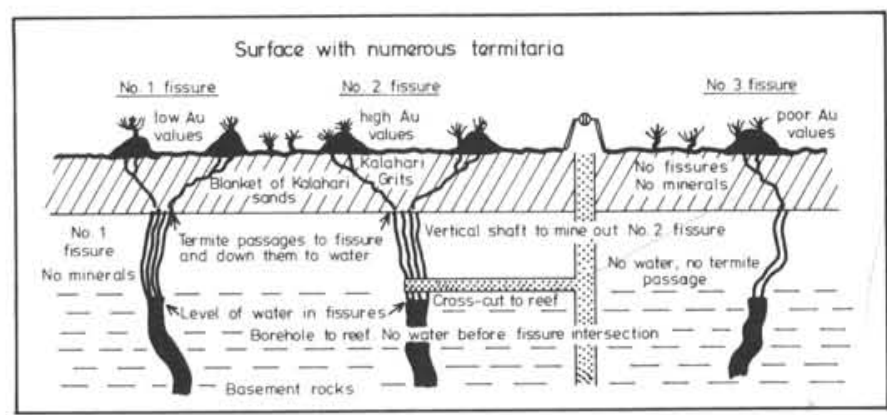

Figure 5: Analysis of termite hills for gold in Zimbabwe (West, 1970). 
Zimbabwe border. The ore deposits were developed in instrusive serpentinite covered by an extensive transported soil, in places more than $15 \mathrm{~m}$ deep. The mounds belonged to the family Macrotermitidae whose members are known to excavate to a considerable depth. Anomalous concentrations of $\mathrm{Ni}$ and $\mathrm{Cu}$ were found above known ore deposits hidden by the deep transported soil (Fig. 6). What may be the ultimate confirmation of efficacy of termites as fjeld assistants comes from the name of a gold mine still operating in Zimbabwe and brought into operation as as result of data from anthills. It is known as the "Termite Mine."

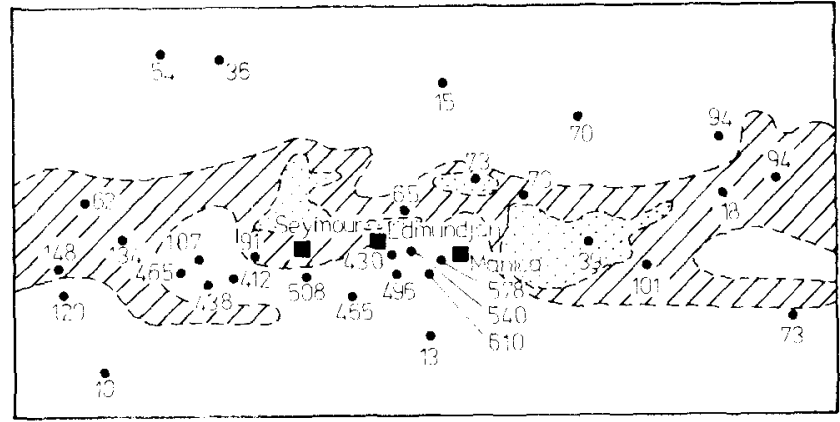

Total copper
in soils $(\mu g / g)$$\left\{\begin{array}{l}\square 0-100 \\ \square 100-400 \\ \square 400 \text { plus }\end{array}\right.$

- Location of termite mounds and their content in $\mu g / g$.

\section{$\stackrel{2}{0} 1000 m$}

Figure 6: Distribution of $\mathrm{Cu}$ in termite mounds and soils in Mozambique. The positions of the known ore occurrences are indicated by solid squares. The concentrations of copper in the soils are poorly correlated with the location of the ores. From D'Orey (1975), with permission from The Institution of Mining and Metallurgy.

\section{Conclusions}

The work summarized in this review has included a number of cases that have sometimes been included for the sake of completeness irrespective of their relevance to mineral exploration. Nevertheless two techniques do stand out as having potential for further work. Perhaps the more promising of these is the sampling and analysis of termitaria. A very large part of Africa (and arid parts of other tropical or semitropical regions such as Australia and South America) is covered with aeolian sands which effectively blanket outcrops and render mineral exploration an expensive and tedious business. The discovery that termites can penetrate this blanket and bring ore minerals to the surface has exciting applications for future work, for example in African countries where Kalahari sands cover large areas. To utilize this potential to the full, further work is needed on the habits of the insects themselves in order to evaluate the relative performance of different species and to determine which parts of the termitaria should be sampled.

The second technique which still has much potential is the use of sniffer dogs. Better training and even better genetic selection should do much to improve the usefulness of these animals. So far dogs have been used exclusively in glaciated areas where prospectors search for mineralized boulders rather than sampling soils or stream sediments. There is no reason, however, why dogs could not be used in tropical areas to compete with termites for searching for minerals below aeolian sands.

Geozoology is probably now at the stage that botanical methods were some 35 years ago when H.V. Warren, a pioneer in this latter field, wrote: "... the reaction to biogeochemistry has changed from one of overall disbelief to benevolent skepticism." I hope that this present review will help to change skeptical attitudes towards geozoology into tolerant acceptance of its potential as yet unexplored.

\section{References}

Beath, O.A., Gilbert, C.S. and Eppson, H.F., 1939. The use of indicator plants in locating seleniferous areas in western United States. American Journal of Botany, Part 1, General,v. 26, no. 4, p. 257-269.

Bollingberg, H.J., 1975. Geochemical prospecting using seaweed, shellfish and fish. Geochimica et Cosmochimica Acta, v. 39, no. 11, p. 1567-1570.

Bollingberg, H.J. and Johansen, P., 1979. Lead in spotted wolffish Anarhichas minor, near a zinc-lead mine in Greenland. Journal of Fisheries Research Board, Canada, v. 36 , no. 9, p. 1023-1028.

Brock, J.S., 1972. The use of dogs as an aid to exploration for sulphides. Western Miner, v. 45, no. 12, p. $28-32$.

Brooks, R.R., Lewis, J.R. and Reeves, R.D., 1976. Mercury and other heavy metals in trout of the central North Island. New Zealand Journal of Marine Freshwater Research, v. 10, p. 233-244.

Butterworth, J., Lester, P. and Nickless, G., 1972. Distribution of heavy metals in the Severn Estuary. Marine Pollution Bulletin, v. 3, no. 5, p. 72-74.

Cannon, H.L., 1957. Description of indicator plants and methods of botanical prospecting for uranium deposits on the Colorado Plateau. U.S. Geological Survey Bulletin, 1030M, p. 399-516.

Chisnall, K.T. and Markland, J., 1971. Contamination of pasture by lead. Journal of Association of Public Analysts, v. 9, p. 116-118.

D'Orey, F.L.C., 1975. Contribution of termite mounds to locating hidden copper deposits. Transactions of Institution for Mining and Metallurgy, Section B, v. 84, no. B28, p. B150-B151.

Ekdahl, E., 1976. Pielavesi: the use of dogs in prospecting. Journal of Geochemical Exploration, v. 5, no. 3, p. 296298.

Grantham, D.A., Jones, J.F., 1977. Arsenic contamination of water wells in Nova Scotia. Journal of American Water Works Association, v. 69, p. 653-657.

Hopps, H.C., 1971. Geographic pathology and the medical implications of environmental geochemistry. Memoirs of Greological Society of America, v. 123, p. 1-11.

Kahma, A., Nurmi, A. and Mattsson, P., 1975. On the composition of the gases generated by sulphide-bearing boulders during weathering and on the ability of prospecting dogs to detect samples treated with these gases in the terrain. Geological Survey of Finland Report, no. 6, 4p.

Makarochkin, B.A., 1972. Spectral data on the mineral composition of honey. Apiakta, v. 7, no. 3, p. 104.

Makarochkin, B.A. and Yudenich, D.M., 1960. Minerals in honey (in Russian). Pchelovodstvo, v. 37, no. 11, p. 34.

Makarochkin, B.A. and Yudenich, D.M., 1962. The trace elements of honey (in Russian). Priroda, v. 51, no. 4 p. 67.

Nilsson, G., 1973. Nickel prospecting and the discovery of the Mjövattnet mineralization North Sweden: a case history of the use of combined technique in drift-covered glaciated terrain. In: M.J. Jones (ed.), Prospecting in Areas of Glacial Terrain, Institution of Mining and Metallurgy, London, p. 97-109.

Orlov, A.P., Robonen, V.I. and Kirilenko, G.M., 1969. Geological Prospecting with Ore-searching Dogs (in Russian). Nedra Press, Moscow, p. 47. 
Razin, L.V. and Rozhkov, I.S., 1966. Geochemistry of Gold in the Crust of Weathering and in the Biosphere in the Gold Ore Deposits of the Kuranakh Type. Nauka Press, Moscow, p. 254.

Severne, B.C. and Brooks, R.R., 1972. A nickel-accumulating plant from Western Australia (Hybanthus floribunda). Planta, v. 103, no. 1, p. 91-94.

Vinogradov, A.P., 1964. Provinces biogéochimiques et leur rôle dans l'évolution organique. Advances in Organic Geochemistry, Earth Science Series Monograph No. 15, p. 317-337.

Ward, J.V., 1973. Molybdenum concentrations in tissues of rainbow trout (Salmo gairdneri) and kokanee salmon (Oncorhynchus nerka) from waters differing widely in molybdenum content. Journal of Fisheries Research Board Canada, v. 30, no. 6, p. 841-842.

Warren, H.V., 1980. Pollen: a possible tool for exploration geologists and environmentalists. Western Miner, March 1980 , p. 35-36.

Warren, H.V., Delavault, R.E., Fletcher, K. and Peterson, G.R., 1971. The copper, zinc and lead content of trout livers as an aid in the search for favourable areas to prospect. Canadian Institute of Mining and Metallurgy Special Volume 11, p. 444-450.

Watson, J.P., 1970. Contribution of termites to development of zinc anomalies in Kalahari sand. Institution of Mining and Metallurgy Transactions, Section B., v. 79, p. B53B59.

Watson, J.P., 1972. The distribution of gold in termite mounds and soils at a gold anomaly in Kalahari sand. Soil Science, v. 113, no. 5, p. 317-321.
Webb, J.S., Nichol, I. and Thornton, I., 1968a. The broadening scope of regional geochemical reconnaissance. Proceedings 23rd International Geological Congress, v. 6, p. 131147.

Webb, J.S., Thornton, I. and Fletcher, K., 1968b. Geochemical reconnaissance and hypocuprosis. Nature, v. 217, p. $1010-1012$

West, W.F., 1965. Some unconventional ideas on prospecting. Chamber Mines Journal (Rhodesia), v. 7, no. 12, p. 40-42.

West, W.F., 1970. The Bulawayo symposium papers: No. 2 "Termite Prospecting". Chamber Mines Journal (Rhodesia), v. 12, p. no. 10, 32-35.

Wild, H., 1975. Termites and the serpentines of the Great Dyke of Rhodesia. Transactions Rhodesia Scientific Association, v. 57, no. 1, p. 1-11.

\section{ABOUT THE AUTHOR:}

Robert R. Brooks is currently Reader in geochemistry at Massey University (Palmerston North, New Zealand). $\mathrm{He}$ is author or co-author of four books and nearly 200 papers primarily in the fields of geochemistry and analytical chemistry. Dr. Brooks' main research interests are in the use of vegetation for mineral prospecting as well as studies on the tolerance of plants to heavy metals.

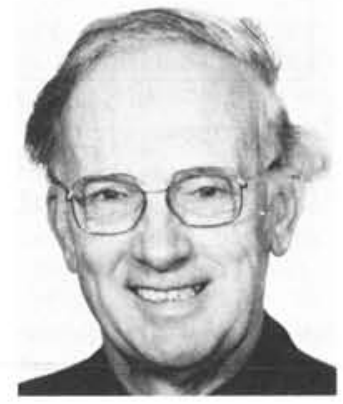

\section{Kail's Geophysical PROJEGTOR}
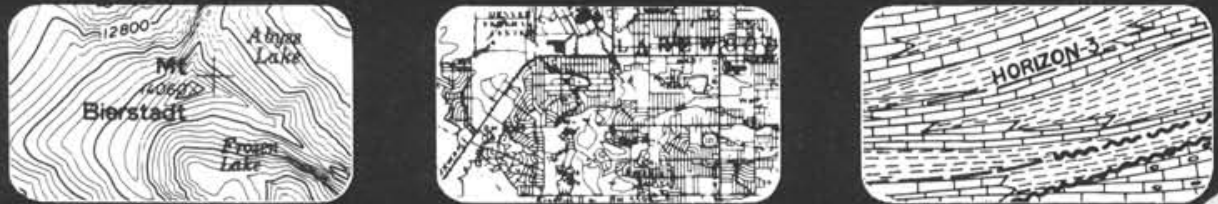

\section{Enlarge or Reduce opaque images}

by automatic focusing

The Model K-A5 Reflecting Projector, ideal for mapping, aerial photography, drawings, layouts and seismic studies. Projector enclosed to form a table top for ease in large material handling. Images are transposed from one glass plane to the other without head or hand interference.

- Image in focus in entire scale range

- Scale from $5 x$ to $1 / 5 x$

- Reflects opaque materials to translucent papers

- Single automatic focus remote control

- Fine focus control knob

- Dimensions 80" long, 30" wide, 36" high

Philip B. Kail Associates, Inc. 1010 West 1st Avenue

Denver, Colorado 80223

(303) 623-5987
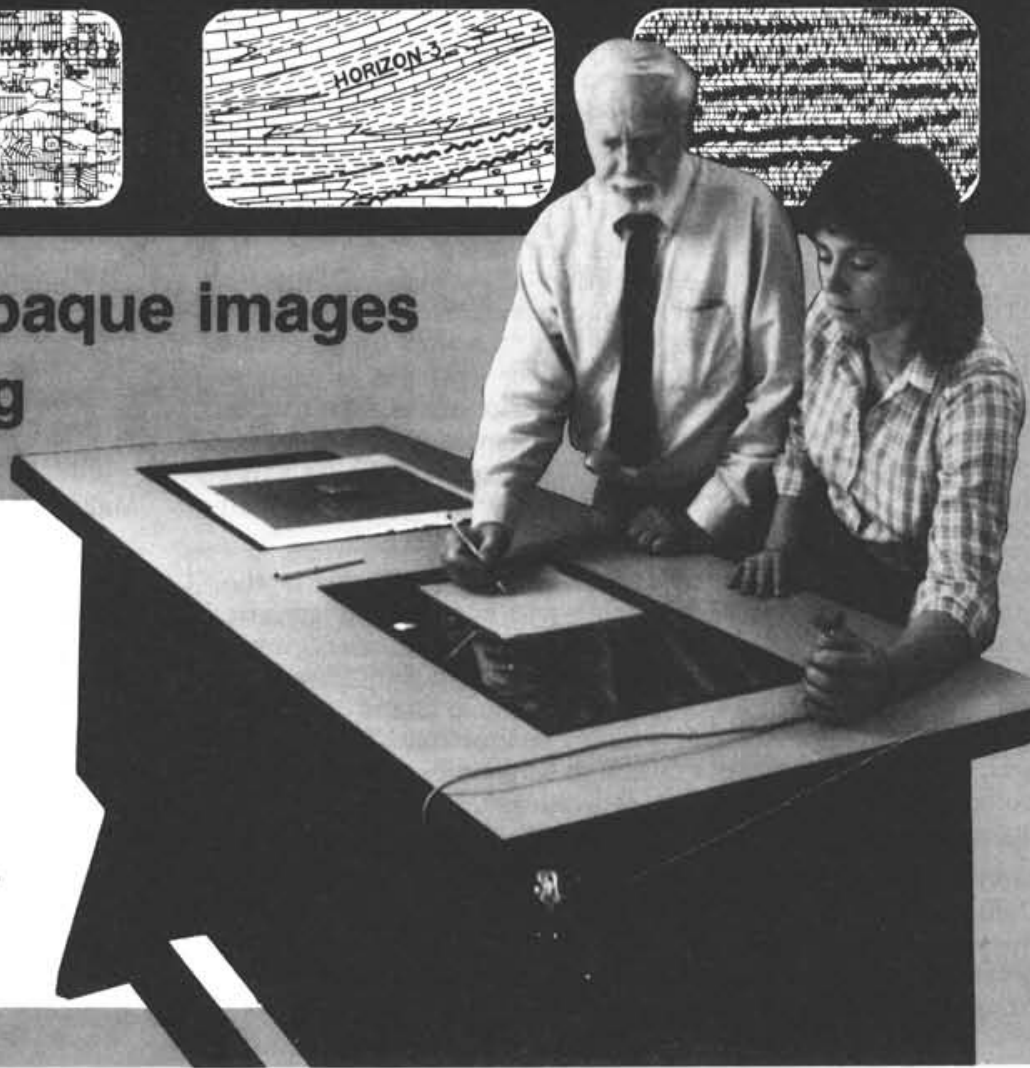

(303) $623-5987$

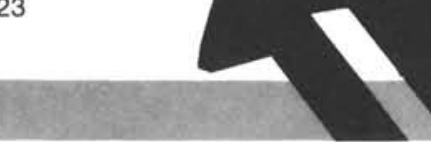

